\title{
Fiscal Regime and Tax Policy in Resource-Rich Countries In The Process Of Globalization: Literature Review
}

\author{
https://doi.org/10.21272/sec.4(2).67-77.2020
}

Hassane Eddassi, ORCID: https://orcid.org/0000-0002-3153-0034

$\mathrm{PhD}$, Economist/Middle Manager, Ministry of Finance, The Kingdom of Morocco

\begin{abstract}
The sudden collapse of oil prices combined with the COVID 19 pandemic is considered to be the worst economic crisis in the history of Resource-Rich Countries. These two events put immense pressure on the economic performance of these countries even with the huge reserves and volume of exports they enjoyed during the past. This raises the question of what are the particularities of these countries that made them very vulnerable to such shocks. This paper is a gathering of multiple studies and reports dealing with the specific topic of Resource-Rich Countries. More precisely, I try to analyze, based on a literature review, the nature of the Fiscal Regime applied in these nations and what makes it different than other countries. In addition, I investigate the Tax Regime applied in Resource-Rich Countries, with an emphasis on observed strengths or weaknesses. I conclude that the Fiscal Regime in Resource-Rich Countries is generally different in many aspects: these countries are subject to severe price volatility, shocks easily affect the economy, and the nature of the Extractive Industry (EI) is very different and needs adequate policy. I also highlight that the Tax System in Resource-Rich Countries is different as well: low investment in human resources and IT and low reliance on tax revenues. This study provides many recommendations to policymakers and authorities in ResourceRich Countries. The most important is the necessity to implement a Counter-Cyclical Fiscal Policy. Such a measure can enhance savings during periods of high prices while allowing the government to spend more during periods of crisis. In addition, the paper recommends investing more in the tax administration and enhancing the volume of tax revenues as this can allow more diversification. Many other recommendations are presented to help absorb the shocks caused by a severe drop in commodity prices. This paper is a good reference for experts or researchers in the fields of Fiscal Regimes, Tax Policy, and Resource Riche Countries. It is also useful for any research in the domain of the Extractive Industries as it analyzes many of the aspects related to that industry.
\end{abstract}

Keywords: resource-rich countries, fiscal policy, tax policy, countercyclical fiscal policy, mining.

JEL Classification: E61, E62, F35, G28, H20.

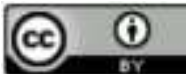

This work is licensed under a Creative Commons Attribution 4.0 International License.

Cite as: Eddassi, H. (2020). Fiscal Regime and Tax Policy in Resource-Rich Countries In The Process Of Globalization: Literature Review. SocioEconomic Challenges, 4(2), 67-77. https://doi.org/10.21272/sec.4(2).67-77.2020.

(C) The Authors, 2020. This article is published with open access at Sumy State University.

\section{Introduction}

Resource-rich countries are defined by the IMF as countries with exports of non-renewable natural resources, such as oil, minerals, and metals, which account for more than $25 \%$ of the value of the country's total exports (Sugawara, 2014) (ED, 2014) (Mohaddes, 2019).

The natural resource, sometimes referred to as "the gift of nature" (Fernando, 2011) (Päivi Lujala, 2012), is able to completely transform the endowed countries because it allows an important increase in the GDP and reduces the reliance on foreign assistance.

Resource-Rich Countries face many challenges such as price volatility, revenue vulnerability, uncertainty of reserves, lack of accountability, and low-quality institutions (Frederick \& Poelhekke, 2006) (Carneiro, 2007) (Benghida, 2017) (Bergougui, Sami, \& Talbi, 2017) (Kaznacheev, 2017). 
Because of these challenges and particularities, Resource-Rich Countries apply specific fiscal regimes to face shocks, ensure a high take for the government from extractive industries, attract investors and participate in the Sustainable Development of the country (Japan, 2016) (Nations, 2016).

In addition, the tax policies adopted by these countries is different than others as it is affected by many factors related to the extractive industries and the structure of the political regime in the nation (Daniel, Keen, \& McPherson, 2010) (Gylfason, Arezki, \& Amadou, 2011) (Samaké, Priscilla, \& Versailles, 2013) (Spies \& Petruzzi, 2014).

This paper is a review of the literature concerning fiscal regimes and tax policies in Resource-Rich Countries. This work is analyzing the several articles and studies conducted to understand how the fiscal regimes and tax policies applied in these countries are different.

\section{Fiscal Management in Resource-Rich Countries}

The first paper in this review is a World Bank study about the extractive industries and the fiscal regimes applied in Resource-Rich Countries. This study sheds light on the specificities of the extractive industry and what makes it different than other industrial sectors.

According to the authors, the extractive industries represent an important share in the economies of many Resource-Rich Countries. The paper states that the sector "accounts for at least 20 percent of total exports, and at least 20 percent of government revenue, in 29 low-income and lower-middle-income countries. In eight such countries, the EI sector accounts for more than 90 percent of total exports and 60 percent of total government revenue".

For investors, the extractive industry bears many risks such as high geological uncertainty, huge investments, and a long period for return on investment. In addition, the sector is characterized by high volatility of prices and costs, which increases the risks related to each project. The graph below shows how prices can fluctuate over a long period:
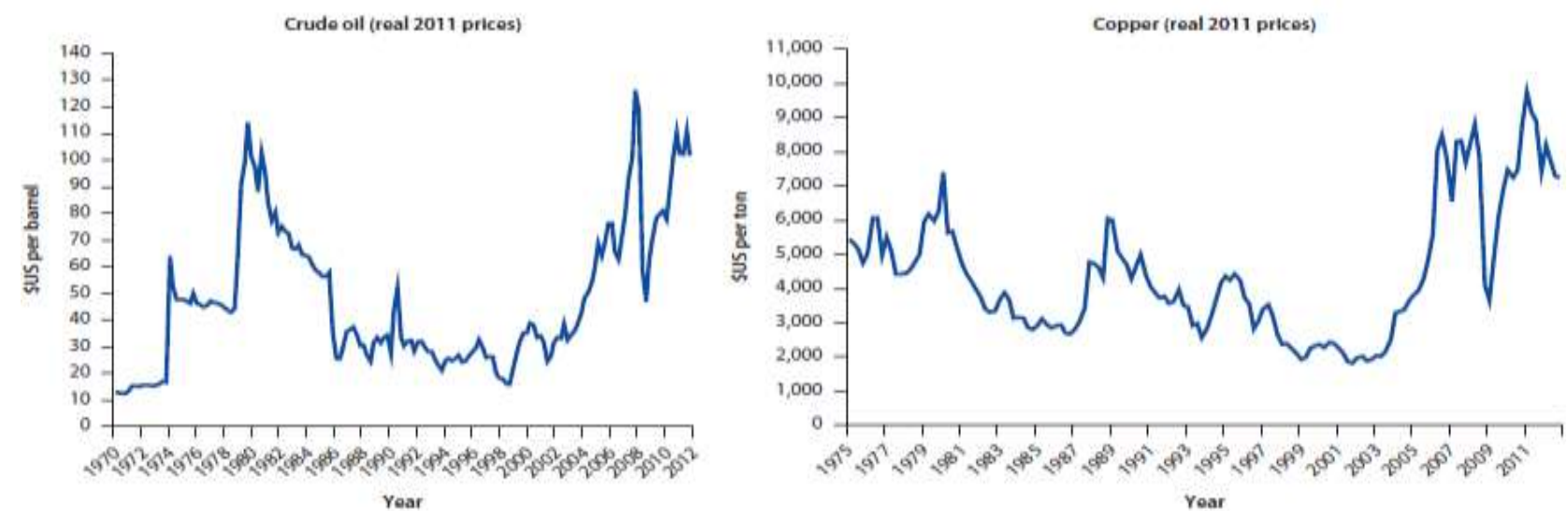

Figure 1. Development in global oil and copper prices, 1970-2012

Source: Fiscal Management in Resource-Rich Countries.

Furthermore, companies are required to support additional costs to reduce the environment effects of the project, participate in the development of the community, and meet specific requirements.

For governments, the issues to consider concern the exhaustibility of the natural resources; the design of the optimal fiscal regime; the allocation of revenues to consumption, investment and saving; and the concerns about intergenerational equity and long term fiscal sustainability. The ultimate objective is to determine the best extraction rates and government take in order to achieve the desired goals.

The EI extractive locations are bound by geography. In fact, extraction projects cannot be relocated to less costly countries, for this reason, companies are taking advantage of tax treaties and innovative financing mechanisms to reduce their tax participation. Fiscal regimes should be innovative and flexible enough to allow both countries and investors to benefit from the natural resource industry. 
To be efficient, the EI needs a complex system of governmental and political institutions. Strong public institutions allow the establishment of a climate favorable to business. It also helps in designing rules and laws that protect the interests of companies while ensures a fair share for the country.

In the next papers, discussions will be conducted to explain how countries can design an efficient fiscal regime and tax system that takes into account all the particularities of the EI.

\section{Macroeconomic Stability in Resource-Rich Countries: The Role of Fiscal Policy}

This paper discusses the macroeconomic stability in Resource-Rich Countries. This analysis is a continuation of the previous paper as it concentrates on fiscal stability and how it is affected in the case of Resource-Rich Countries.

Because of the nature of their economy, Resource-Rich Countries are always subject to severe shocks. In addition, the volatility of commodity prices increases the risks of long and continuous shocks.

This paper starts from the assumption that Resource-Rich Countries are supposed to adopt countercyclical fiscal policies to avoid negative effects caused by the volatility of commodity prices. This assumption is explained by the fact that a countercyclical fiscal policy allows Resource-Rich Countries to spend more in case of a large drop in prices.

The paper analyzes a population of 48 non-renewable commodity exporters for the period 1970-2014 to test the veracity of this assumption. Further, it assesses how fiscal policy impacts macroeconomic stability and investigates the role of political institutions in implementing the fiscal policy.

The paper argues that Resource-Rich Countries are adopting a procyclical fiscal policy, contrary to the assumption. This is illustrated by the fact that these economies tend to spend more during price booms but adopt austerity policies and cut spending during periods of low commodity prices. According to the paper, this procyclicality leads to: "volatility and potentially much weaker growth".

Concerning the role of political institutions, the paper states that with the existence of strong institutions and compliance with the rules, procyclicality can be reduced as these institutions can intervene in the fiscal policy and enforce the application of more beneficial measures during booms or busts. According to the paper, the persistence of procyclicality over the years in these countries is largely due to the low quality of political institutions.

The figure below illustrates the quality of the institutions in Resource-Rich and Resource-Poor countries:

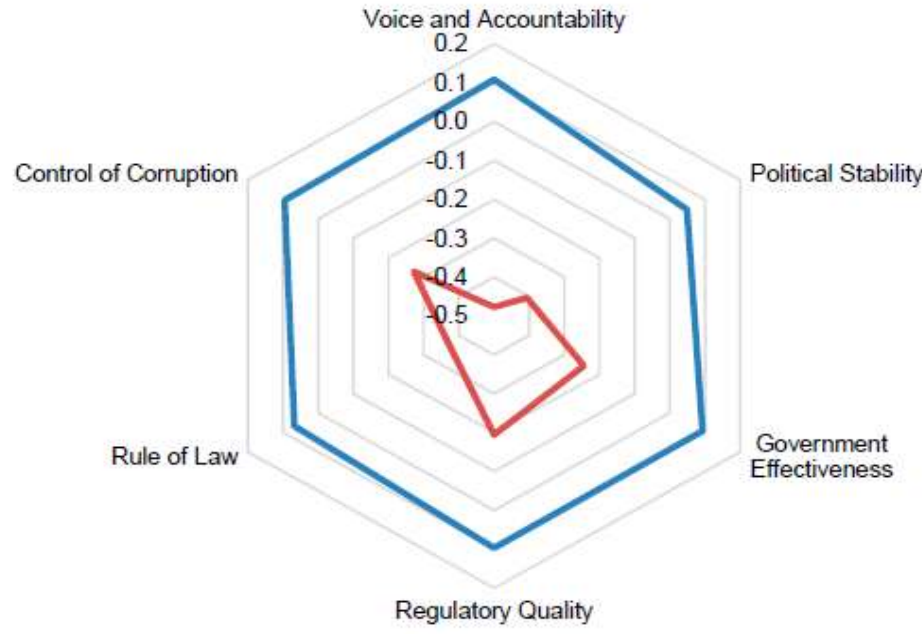

Resource-poor $\quad$ Resource-rich

Figure 2. Institutional quality in resource-rich countries is weaker than in other countries

Source: Macroeconomic Stability in Resource-Rich Countries: The Role of Fiscal Policy. 
In conclusion, the paper suggests the adoption of a comprehensive fiscal policy framework in Resource-Rich Countries to face uncertainty and volatility, in addition to the improvement of the institutional framework to enhance transparency and accountability.

These recommendations are the basis for the next paper with an emphasis on Resource-Rich Developing Countries.

\section{Macroeconomic Policy Frameworks for Resource-Rich Developing Countries}

Based on the recommendations of the previous paper, this study is suggesting a fiscal policy framework proper to Resource-Rich Developing Countries. The objective is to assist these countries in order to benefit from resource wealth and ensure Sustainable Development.

The paper suggests devoting a high portion of resources to saving and investment instead of consumption. The goal is to convert exhaustible resource wealth into other assets by investing mainly in human capital, domestic -public and private- capital, and foreign financial assets.

In addition, the paper suggests delinking government spending form commodity price volatility. In this regard, the authors state that Resource-Rich Countries are known for procyclicality, as they witness an increase in investment and saving during booms and a reduction of expenditure following price shocks. This policy leads to less effective government spending which can hurt the economy as a whole.

In presenting suggestions, the paper is stressing out the necessity to consider the long-term horizon. When designing a policy framework, countries should take into account uncertainty, as the resource reserves can be either proven or unproven. This makes projecting long term prices and reserves very difficult. For this reason, the paper is giving advice according to the horizon of resource depletion:

$>$ In the case of countries with long-lasting resource reserves, the major challenges are to ensure Sustainable Development and avoid excessive borrowing.

$>$ For countries with uncertain reserve horizon, the fiscal regime should be accompanied by alternative scenarios and contingency plans. There is also a need to make regular updates in response to new information.

$>$ For the last category of countries, those with short term reserve horizon, the focus should be on enhancing the quality of saving and investment decisions, while ensuring fiscal sustainability.

To support Sustainable Development in Resource-Rich Developing Countries, the paper recommends the establishment of stronger economic and political institutions, the creation of liquidity funds (financed during price booms and used to smooth consumption spending during periods of price drops), and the utilization of financial instruments to hedge price risks. Resource-Rich Countries should adopt additional indicators on resource use and establish fiscal sustainability benchmarks.

\section{Fiscal Frameworks for Resource-Rich Developing Countries}

As in the previous paper, this document proposes a fiscal framework for Resource-Rich Developing Countries, with an emphasis on low-income countries.

The main objective of the paper is to provide a more flexible fiscal framework. The designed regime should take into account the economic and institutional specificities of the country (dependency on resource revenue, reserve horizon, development needs...). According to the paper, "simple modifications to fiscal frameworks currently in use allow a more flexible treatment of growth-enhancing expenditure while addressing both the volatility and exhaustibility of resources revenue". A very well implemented fiscal regime reduces the effects of volatility, uncertainty, and exhaustibility while ensuring macroeconomic and fiscal stability.

The paper presents a decision tree to determine fiscal framework priorities: 


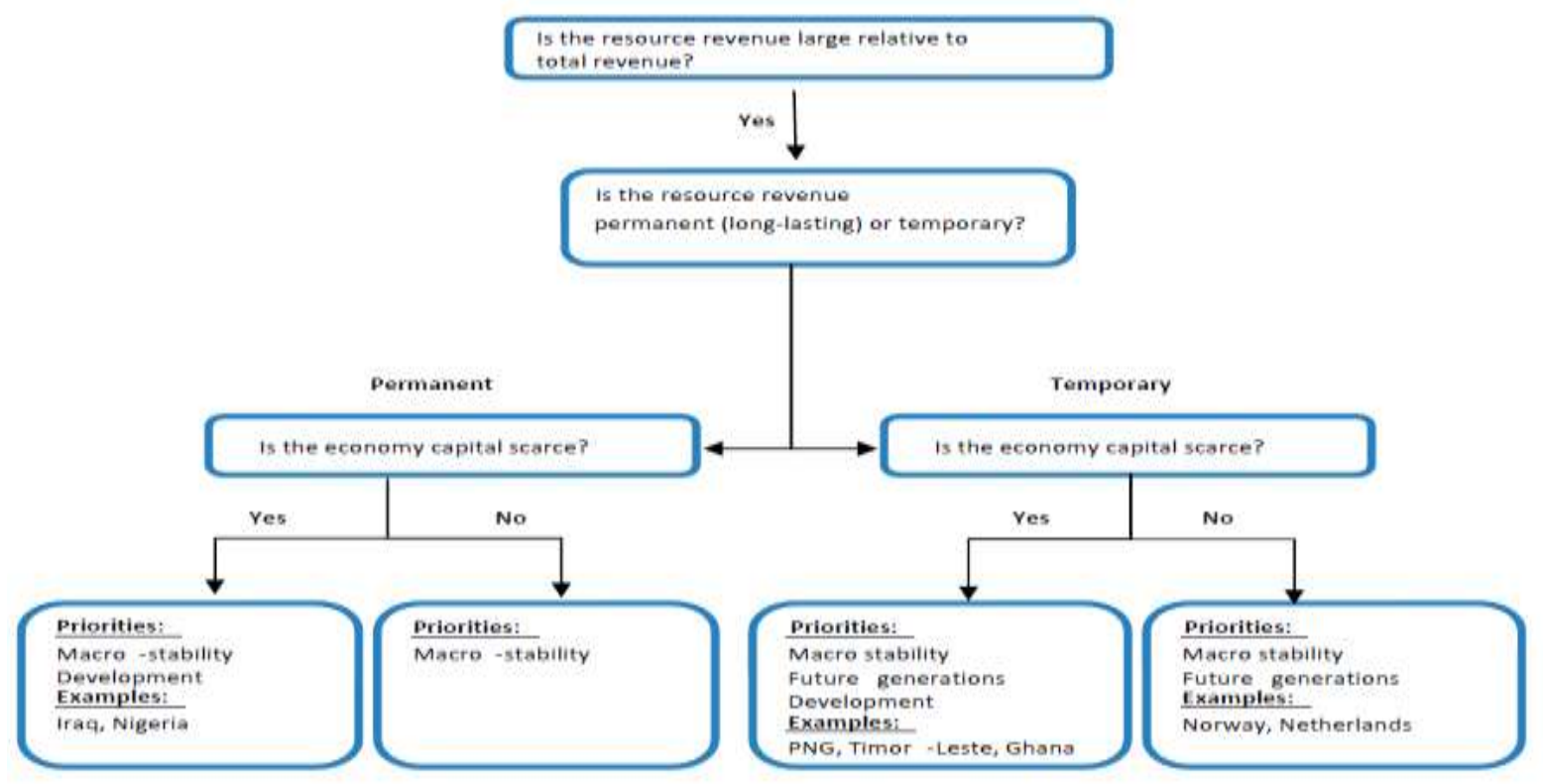

Figure 3. Decision Tree for Fiscal Framework Priorities

Source: Fiscal Frameworks for Resource-Rich Developing Countries.

Concerning the recommendations, the paper suggests enhancing domestic investment, building up physical and human capital, and creating precautionary saving funds to support the credibility and transparency of fiscal policy framework.

To analyze the effects of these recommendations on the economy, the paper proposes a set of indicators to be used:

$>$ The non-resource primary balance (the primary balance minus (net) resource revenue, preferably scaled to non-resource GDP),

$>$ The overall (or primary) balance,

$>$ The current balance,

$>$ The domestic balance (the overall fiscal balance excluding transactions with the rest of the world).

The paper discussed the fiscal regime in Resource-Rich Countries, with a focus on low-income countries. To push further the analysis, the next paper studies the fiscal regime in some African Resource-Rich Countries.

\section{Fiscal Regimes in Resource Dependent African States: A Political Economy Game}

As mentioned before, this paper focuses more on African countries classified as Resource-Rich. The objective of the study is to discuss how to improve accountability and quality of life in African Resource-Rich Countries by designing an effective fiscal regime.

In many African countries, challenges to face are related to poverty alleviation, trade liberalization, and social services provision to citizens. These economic programs necessitate huge funding that is generally provided by foreign sources or concessional loans from the west. Yet, most African countries have internal fiscal revenues that can be utilized to ensure Sustainable Development, and especially, countries with natural resource wealth.

In discussing the paradox of African nations (enjoying resource wealth while being poor countries), the authors suggest three main explanations:

$>$ In African Resource-Rich Countries, the discovery of natural resources resulted in a huge amount of free and easy money injected into the economy. The nature of political institutions and the weak structure of the economy could not effectively deal with this flow of money. Resource wealth was not a source of development in many of these countries. This is explained by the lack of accountability, the inexistence of efficient economic plans, and the contraction of the industrial sector due to the development of the oil sector (crowding out of investments in other sectors). 
$>$ The natural resource windfalls available in the country make governance profitable and lucrative which motivates the political elite to remain in power. This situation provokes misallocation of the wealth as it is utilized to preserve the power instead of investing in the economic development of the country.

$>$ The lack of accountability is explaining the weak growth in these countries. In fact, with no strong civil society organizations and political institutions, government leaders have the incentive to engage in corruption and illegal practices, which in turn leads to the failure of the economy and mismanagement of the resource wealth.

On the other hand, the authors stress out the fact that the existence of resource wealth in the African countries lead to a weak taxation system. The paper gives three reasons for this:

$>$ The resource-endowed countries benefit from easy revenue generated by the natural resource industry, and hence, there are no incentives to establish a taxation system as the government is guaranteed to raise the necessary funds.

$>$ Revenues generated from resource wealth are exogenously determined and, most of the time, unaccounted for. In contrast, revenues collected from a tax system will generate demands for accountability because they are provided by citizens. Political elites in these countries are trying to avoid accountability as mentioned above.

$>$ Finally, non-tax revenues affect less the electorate compared to tax revenues. Political leaders prevent the establishment of a tax system to remain in power by lowering the burden on citizens.

As a conclusion, the paper proposes the application of a progressive fiscal regime allowing the taxation of high incomes which will participate in reducing inequalities in the society. Furthermore, African ResourceRich Countries have to devote part of the resource wealth to develop the taxation system by hiring and training qualified human resources, investing in new technologies, and enforcing accountability.

\section{Fiscal Regime Design. What Revenues the Government Will be Entitled to Collect}

This paper is the first in this review to discuss tax revenues in Resource-Rich Countries. After analyzing the design and nature of the fiscal regimes applied in Resource-Rich Countries, we can discuss the other part of this review, which is related to the revenues collected by the government and how they are implemented.

This article starts by presenting its main objectives, namely: the factors to consider when selecting a fiscal regime, the fiscal tools commonly used by governments, and the potential loopholes that may arise.

For the first point, which debates the factors to consider when designing a fiscal regime, the authors stress out the fact that policymakers should consider both the interest of the government and corporations (to attract and retain investments). In this regard, three factors are taken into account:

$>$ Timing of the revenue: most projects in the resource industry will not make a profit in the very first years. The huge investments in infrastructure and equipment make the return on investment period very long. Based on this, governments can set fiscal regimes that may provide revenues in the early stage of the extractive project or taxing profit when achieved (after a long period).

$>$ Change of government revenue with a change in profitability: the extractive industry is characterized by its uncertainty and volatility in the production techniques and rates. Quantities extracted change, up and down, over time; hence, the profit of the project is not stable over its life cycle. In this case, the fiscal regime applied by the authorities can be based on one of three choices: neutral fiscal tools (same tax is paid), progressive fiscal tools (the tax increases as the profit gets higher) and regressive fiscal tools (the tax decreases as the profit gets higher).

$>$ Risk: two factors make the extractive industry very risky. The first is the huge amount of investment needed and the second is the uncertainty to make a future profit to cover the investment. The fiscal regime should take into account the risk of the project and determine how this risk is shared between the government and the company.

After discussing the factors to take into account when designing a fiscal regime, the second part of the article is the analysis of the different tools used by governments. We can mention Royalties, Corporate Income Tax, Bonuses, Production Sharing...

As an example, the paper provides a figure showing a typical revenue flows in a production sharing contract. This is presented in the figure below: 


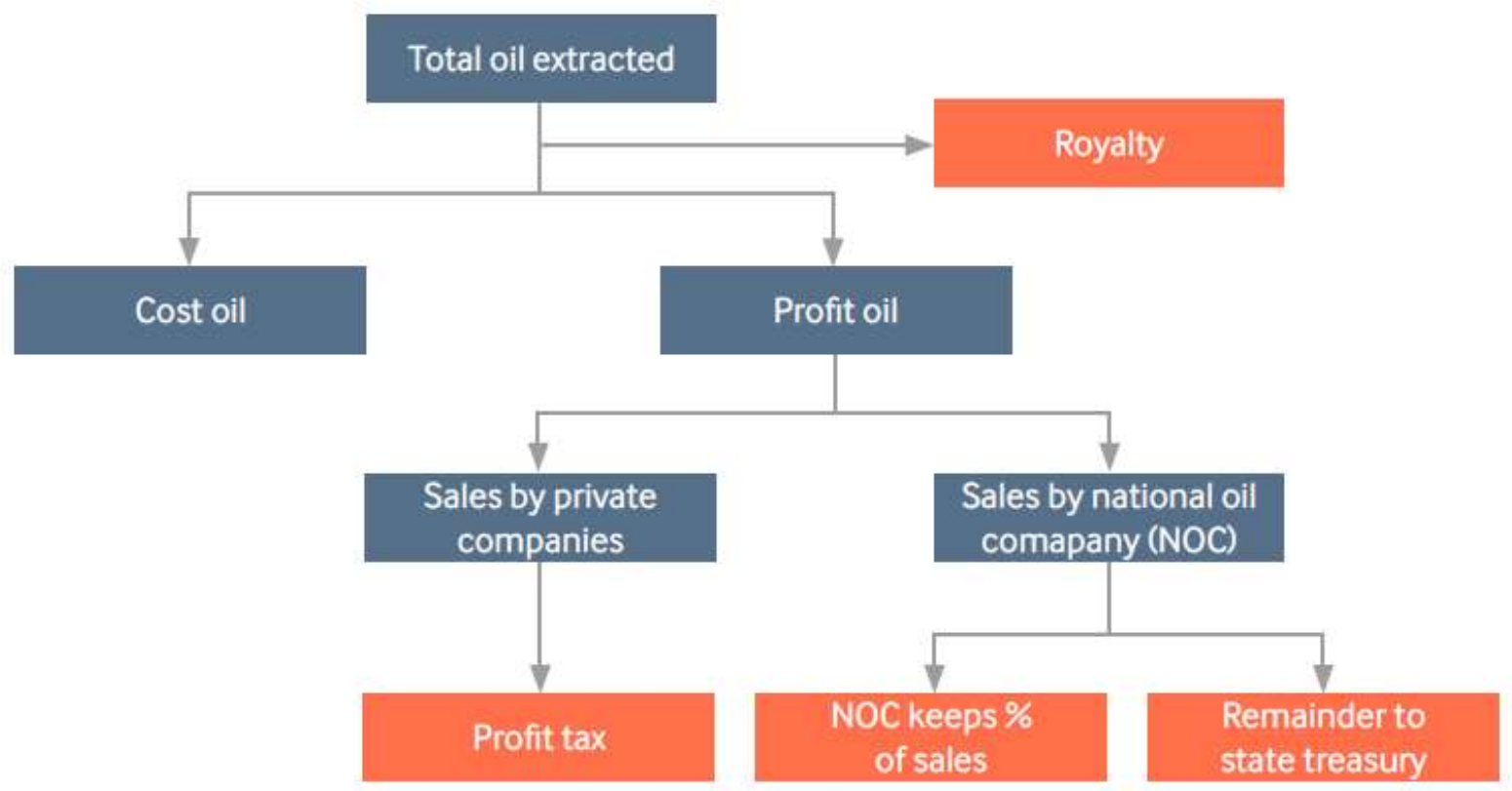

Figure 4. Typical Production Sharing Contract

Source: Fiscal Regime Design. What Revenues the Government Will be Entitled to Collect.

The choice of the tool or tools to use depends on the factors mentioned above. The government can specify the tools to use in the legislation or can establish individual contracts for each project. In addition, these tools can be inserted into laws specific to the industry (such as mining law or petroleum act) but also in general legislation such as tax law.

The final point in the article is the pitfalls and loopholes used by companies to lessen the amount of tax to pay. Among these loopholes, we can mention:

Transfer pricing: the transfer of taxable profit from a country with a high tax rate to another jurisdiction with low rates. Usually, this practice is implemented by companies managing multiple subsidiaries all over the world.

$>$ Thin capitalization: this practice is used by companies when they are allowed to deduct interests on loans. In this case, the company uses an important amount of debt to finance the project and at the same time reduces taxable income by deducting the interest.

$>$ Production costs: companies try to increase the production cost in order to reduce taxable income. This is done using inaccurate accounting practices or spending unnecessary amounts on production.

It can be concluded that the taxation of the natural resource industry should take into account the financial needs of the government while preserving the interests of the companies. This question is the main idea discussed in the following paper.

\section{Extractive Industries Taxation}

This paper discusses the factors to take into account when designing a fiscal regime intended to collect revenues from extractive industries. Contrary to the previous paper, this one presents factors to consider in the viewpoint of resource holders (the government) and the investor.

Resource holder considerations:

Overall fiscal take: the government taxes from the extractive industry should be completed by other forms of takes that can contribute to the general development of the economy. This includes infrastructure development by corporations, contribution to community projects, hiring and training of national employees, sourcing from local suppliers...

$>$ Timing: the paper presents the same factors related to timing as those mentioned in the previous article. 
$>$ Competitiveness: when setting up a fiscal regime, the paper recommends that the government should take into account the risks associated with the extractive industry. The level of tax rates must be relevant to the risks faced by companies. Tax incentives make the country competitive and attract more investors.

$>$ Interaction with pre-existing legislation: policymakers should take into account the existing legislation when preparing a fiscal regime. In general, rules to tax extractive industries must consider also the tax law to avoid excessive burden on companies that may discourage investment in this field.

Investor consideration:

$>$ Risk/reward: before investing in a country, corporations have to evaluate the level of risks they are able to support. The paper states that "In the global competition for limited capital and human resources, investing companies will seek investment opportunities which offer the best risk/reward balance".

$>$ Stability: companies are looking for projects with stable future horizon. In this regard, the paper suggests that the tax system should be stable over the future. This can allow companies to make decisions in the long run with clear visibility regarding the life cycle of the project.

$>$ Predictability: companies should be able to predict changes in the fiscal regime and tax law of the nation. To guarantee the attractiveness of the country, the government should engage the companies in the legislative decision-making process.

$>$ Ownership of underlying reserves: the country's law should clearly indicate the ownership state of the discovered reserves. This is usually measured using the Reserves Replacement Ratio (RRR). "Company would have an RRR of $100 \%$ if, for every barrel of hydrocarbon produced, another barrel is found/discovered and booked via exploration".

As far as taxation is concerned, this paper concludes by recommending the improvement of the capabilities of the tax administration. This can be achieved by training staff, providing appropriate audit tools and equipment, knowledge sharing with other countries and departments...

The previous two papers discussed the design of a tax regime helping the government to take advantage of the natural wealth. Many factors should be taken into account as already mentioned. The next paper continues this study by discussing the vulnerabilities affecting tax revenues in Resource-Rich Countries.

\section{Vulnerability of Tax Revenue in Resource-Rich Countries}

The previous two papers presented an overview of the tax systems which can be applied in Resource-Rich Countries. This article discusses the vulnerabilities affecting the tax revenues in the case of Resource-Rich Countries. As commodity prices are very volatile, the revenues generated can fluctuate heavily and are subject to shocks caused by the internal and external environment.

The authors are discussing two topics in this paper:

$>$ The impact of external shocks on revenue volatility. This is explored by analyzing the effect of the Exchange Rate Pressure Index and Terms of Trade (ToT). The analyzed population is composed of 176 countries for the period 1980-2010.

$>$ The influence of government factors on vulnerability. The paper investigates the behavior of countries according to the income level, political regime type, and government effectiveness.

The result of the analysis yields the following findings:

$>$ Concerning the effects of Exchange Rate shocks: the impact is high on revenues earned by both ResourceRich and Non-Resource countries. Inside the Resource-Rich group, the lower-income category is more affected by the volatility resulting from Exchange Rates. For the Terms of Trade, the Resource-Rich Countries are less affected by this shock. The impact of ToT is even small in the case of low-income countries.

$>$ Concerning the impact of the government structure: non-democratic regimes are more vulnerable to shocks, and resource revenues are indeed very volatile in this case. The findings show also that ResourceRich Countries with high levels of governance are subject to external shocks. According to the paper, this is "perhaps due to higher degree of world market integration and reliance on external borrowing as an insurance mechanism". 
The paper concludes that even with the existence of revenue volatility in Resource-Rich Countries, the vulnerability has decreased in the 2000s compared to the previous two decades. A fact explained by the enhancement of the government management of natural resource wealth.

The topic of tax revenues and vulnerability is very crucial as it can affect government plans for economic development. As it is suggested by most of the papers in this review, the fiscal regimes and tax systems in Resource-Rich Countries are dependent on the quality of the institutions. In the next two papers, the impact of institutions is discussed along with the way to enhance the quality of governing in Resource-Rich Countries.

\section{The Political Economy of Natural Resource Taxation: Building Credibility and Investing in Tax Administration Capacity}

In discussing the role of tax administration in Resource-Rich Countries, the paper initiates the analysis by insisting on the fact that the majority of Resource-Rich Countries (and especially low-income category) have little capacity and poor management of revenue administration. Many reasons are presented by the authors such as inadequate organizational structure, unskilled staff, poor incentives, and lack of information technology structure.

Governments in Resource-Rich Countries have less incentive to modernize and reform tax administration. According to the article, this is explained, first, by the important investments needed in such cases (infrastructure and human resource). Second, the windflaws of revenue generated by the natural resource industry necessitate low or no audit skills from a structured tax administration. And finally, the political elite is discouraged to create an efficient tax administration to avoid taxing citizens and affect the electoral base which may harm the legitimacy of the political regime. The authors stress out that in the low-income ResourceRich Countries, the need for improving tax administration is urgent because it can substantially enhance government revenues needed to develop the country.

In order to help governments collect a fair share from the extractive industries, the paper presents the following recommendations:

$>$ Designing tax systems based on country specificities. The authors recommend adopting a progressive profit-based tax system as it ensures revenue efficiency and flexibility. The paper states that "the design of a detailed good-enough regime must be commensurate with the country specific political, economic, and institutional setting".

$>$ Invest in the tax administration capacity. An efficient tax administration (in terms of institutional and organizational dimension) will increase the government take and improve the incentives proposed to attract investors. An investment in the tax administration will enhance the credibility and transparency of the tax policy.

$>$ Encourage transparency, capacity, and credibility. Resource-Rich Countries are required to encourage transparency capacity and credibility. Applying these elements is important in creating a good-enough fiscal regime.

\section{Special Fiscal Institutions for Resource-Rich Developing Economies}

The final paper in this review deals with what is called Special Fiscal Institutions (SFIs), which are mechanisms implemented by Resource-Rich Countries to handle the challenges they face and promote fiscal discipline. According to the paper, SFIs "typically include fiscal rules, resource funds, fiscal responsibility laws, and fiscal advisory councils". More than one SFI can be implemented at a time to guarantee an efficient fiscal regime and properly manage resource revenues. For SFIs to be effective, many conditions must be present in a country. This includes stable institutions, strong Public Financial Management system, and a political commitment to fiscal discipline.

The authors present three options for the Developing Resource-Rich Countries when deciding to implement any SFI. First, in the absence of a favorable environment to apply the SFIs, they should be ignored and not implemented. Second, a country can apply policies aimed at managing the resource revenues, without committing to SFI guidelines. And finally, the country could implement the SFIs and establish a learning process to detect which elements work better. 
The option to be chosen by a country must take into account the objectives to be achieved. The paper gives examples such as "whether to stabilise macroeconomic volatility, frontload expenditure to address capital and labour constraints, save for future generations, and/or initiate cash transfers, etc".

When deciding to adopt the SFIs system, the factors to consider are:

$>$ The adopted SFI should be integrated into the country's Public Financial Management system. As such, any revenue generated by the resource sector or the wealth fund should be integrated into the national budget; resource revenues should be transparently presented in the budget; and earmarking resource revenue for specific expenditure items should be avoided.

$>$ The country should adopt SFIs rules that are simple to understand and permit a certain degree of flexibility. This should be accompanied by fiscal responsibility rules and procedural laws, in addition to independent supervision and audit committees.

$>$ To be effective in managing resource revenues, governments have to invest in promoting transparency. Many initiatives are presented by the paper such as the Open Budget Initiative or the Global Initiative for Fiscal Transparency and The Extractive Industries Transparency Initiative.

As a conclusion, the paper recommends to avoid using SFIs as a sole solution to the challenges faced by Resource-Rich Countries. Also, it is not preferred to apply other countries' experiences without taking into account the specificities of the local economy. The authors also encourage experience sharing between countries accompanied by mutual discussions to design the best-fitted fiscal regime.

\section{Conclusion}

This overview of the literature showed the particularities of the Resource-Rich Countries and how important a specific fiscal regime is. Designing a productive fiscal regime requires the establishment of an environment of transparency and accountability in addition to strong political institutions. Furthermore, to benefit from the extractive industries, the government should invest in modernizing tax administration to set up an adequate tax system able to ensure fiscal sustainability.

The current crisis caused by the Corona Virus and petrol price war is an alarm signal for these countries. The necessity for quick and inclusive measures is becoming urgent to reduce the effects of such shocks. This paper is a valuable source of information to policymakers and researchers in order to confront the current situation and make the economy stronger and able to face any potential crisis in the future.

\section{References}

1. Benghida, S. (2017). Factors and challenges in developing countries under the resource curse. International Journal of Civil Engineering and Technology. IAEME Publication. https://hal.archives-ouvertes.fr/hal01653339/document

2. Bergougui, B., Sami, L., \& Talbi, B. (2017). Natural Resources, Institutional Quality and economic development in Oil-Rich Countries: The case of Arab Countries. MECAS. https://www.researchgate.net/publication/316275008_Natural_Resources_Institutional_Quality_and_econo mic_development_in_Oil-Rich_Countries_The_case_of_Arab_Countries

3. Carneiro, F. G. (2007, April). Development Challenges of Resource-Rich Countries: The Case of Oil Exporters. SSRN Electronic Journal. https://papers.ssrn.com/sol3/Delivery.cfm/SSRN ID990091 code114733.pdf?abstractid=990091\&mirid=1

4. Daniel, P., Keen, M., \& McPherson, C. (2010). The Taxation of Petroleum and Minerals: Principles, Problems and Practice. Routledge.

5. ED, I. (2014, October). Resource-rich countries in Sub-Saharan Africa (SSA). IBIS Education for Development. $\quad$ https://oxfamibis.dk/sites/default/files/media/pdf_global/aap_pdf/map_of_resourcerich_countries_in_sub-saharan_africa_final.pdf

6. Fernando, A. (2011). Business Environment. Pearson Education India. https://books.google.com.ua/books/about/Business_Environment.html?id=xaHonZv5dfIC\&redir_esc=y

7. Frederick, v. d., \& Poelhekke, S. (2006). Volatility and the Natural Resource Curse. OxCarre Research Paper. University of Oxford. https://www.jstor.org/stable/27784157?seq=1

8. Gylfason, T., Arezki, R., \& Amadou, N. R. (2011). Beyond the Curse: Policies to Harness the Power of Natural Resources. International Monetary Fund. 
https://www.imf.org/en/Publications/Books/Issues/2016/12/31/Beyond-the-Curse-Policies-to-Harness-thePower-of-Natural-Resources-24843

9. Japan, I. C. (2016, March). Study on Economic and Fiscal Policies in Resource-Rich Countries. https://openjicareport.jica.go.jp/pdf/12262085.pdf

10. Kaznacheev, P. (2017, February ). Curse or Blessing? How Institutions Determine Success in Resource-Rich Economies. Cato Institute Policy Analysis. Cato Institute. https://papers.ssrn.com/sol3/Delivery.cfm/SSRN_ID2919443_code1953816.pdf?abstractid=2919443\&mirid=1

11. Mohaddes, K. (2019). Institutions and Macroeconomic Policies in Resource-Rich Arab Economies. Oxford University Press. https://global.oup.com/academic/product/institutions-and-macroeconomic-policies-inresource-rich-arab-economies-9780198822226?cc=ua\&lang=en\&

12. Nations, U. (2016). Extractive Industries Taxation. https://www.un.org/esa/ffd/wpcontent/uploads/2018/05/Extractives-Handbook_2017.pdf

13. Päivi Lujala, S. A. (2012). High-Value Natural Resources and Post-Conflict Peacebuilding. Routledge. https://www.routledge.com/High-Value-Natural-Resources-and-Post-Conflict-Peacebuilding/LujalaRustad/p/book/9781849712309

14. Samaké, I., Priscilla, S. M., \& Versailles, B. (2013). Fiscal Sustainability, Public Investment, and Growth in Natural Resource-Rich, Low-Income Countries: The Case of Cameroon. International Monetary Fund. https://www.imf.org/en/Publications/WP/Issues/2016/12/31/Fiscal-Sustainability-Public-Investment-andGrowth-in-Natural-Resource-Rich-Low-Income-40644

15. Spies, K., \& Petruzzi, R. (2014). Tax Policy Challenges in the 21st Century. Linde Verlag GmbH. https://papers.ssrn.com/sol3/papers.cfm?abstract_id=3222507

16. Sugawara, N. (2014). From Volatility to Stability in Expenditure: Stabilization Funds in Resource-Rich Countries. International Monetary Fund. https://hal.archives-ouvertes.fr/hal-01653339/document

17. Fiscal Management in Resource-Rich Countries (2016). A World Bank Study. Rolando Ossowski and Håvard Halland. World Bank Group. https://openknowledge.worldbank.org/bitstream/handle/10986/24577/9781464804953.pdf?sequence=2\&isA llowed=y

18. Macroeconomic Stability in Resource-Rich Countries: The Role of Fiscal Policy (2016). IMF Working Paper. Elva Bova, Paulo Medas, and Tigran Poghosyan. Fiscal Affairs Department. International Monetary Fund. https://www.imf.org/external/pubs/ft/wp/2016/wp1636.pdf

19. Macroeconomic policy frameworks for resource-rich developing countries (2012). International Monetary Fund. https://www.imf.org/external/np/pp/eng/2012/082412.pdf

20. Fiscal Frameworks for Resource-Rich Developing Countries (2012). Thomas Baunsgaard, Mauricio Villafuerte, Marcos Poplawski-Ribeiro, and Christine Richmond. https://www.imf.org/external/pubs/ft/sdn/2012/sdn1204.pdf

21. Fiscal Regimes in Resource Dependent African States: A Political Economy Gam e. Temitope J. Laniran. African Governance and Development Institute. https://www.econstor.eu/bitstream/10419/173643/1/agdiwp-17-037.pdf

22. Fiscal Regime Design: What Revenues the Government Will be Entitled to Collect (2015). Natural Resource Governance Institute. https://resourcegovernance.org/sites/default/files/nrgi_Fiscal-Regime-Design.pdf

23. Extractive Industries Taxation. Government Fiscal Take. https://www.un.org/esa/ffd/wpcontent/uploads/2016/10/12STM CRP3 AttachmentE FiscalTake.pdf

24. Vulnerability of Tax Revenue in Resource-Rich Countries. Christian von Haldenwang and Maksym Ivanyna. German Development Institute. https://msu.edu/ ivanynam/research/taxrev_rr/Haldenwang_Ivanyna_Tax_Vuln_RR_2015.pdf

25. The Political Economy of Natural Resource Taxation: Building Credibility and Investing in Tax Administration Capacity. Tuan Minh Le and Lorena Viñuela. http://documents.worldbank.org/curated/en/888451468167353276/pdf/703090WP0P11450te0030Taxation0 Final.pdf

26. Special Fiscal Institutions for Resource-Rich Developing Economies (2013). Natasha Sharma and Tove Strauss. Overseas Development Institute. https://www.odi.org/sites/odi.org.uk/files/odi-assets/publicationsopinion-files/8393.pdf 